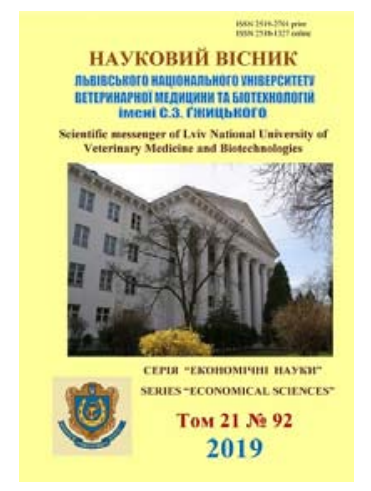

\section{Науковий вісник Дьвівського національного університету ветеринарної медицини та біотехнологій імені С.3. Гжицького. Серія: Економічні науки}

\author{
Scientific Messenger of Lviv National University \\ of Veterinary Medicine and Biotechnologies. \\ Series: Economical Sciences
}

ISSN 2519-2701 print

\title{
Synergistically-reflexive model of management as a single social organism
}

\author{
P.I. Berko, M.M. Dzera \\ Stepan Gzhytskyi National University of Veterinary Medicine and Biotechnologies, Lviv, Ukraine
}

Article info

Received 04.02.2019

Received in revised form 08.03 .2019

Accepted 11.03.2019

Stepan Gzhytskyi National University of Veterinary Medicine and Biotechnologies Lviv, Pekarska Str., 50, Lviv, 79010, Ukraine.

Tel.: +38-067-309-14-96 E-mail:philosophy@lvet.edu.ua
Berko, P.I., \& Dzera, M.M. (2019). Synergistically-reflexive model of management as a single social organism. Scientific Messenger of Lviv National University of Veterinary Medicine and Biotechnologies. Series: Economical Sciences, 21(92), 172-176. doi: 10.32718/nvlvet-e9230

Nowadays, as the system of scientific knowledge itself is radically implemented, the clear boundaries between practical and cognitive activity are eroded. In the system of scientific knowledge there are intensive processes of differentiation and integration of knowledge, complex researches, new ways and methods of cognition, methodological installations, new elements of the world picture are developed, the earlier unknown, more complex types of objects of cognition characterized by historicism, universality, the complexity of organizations that had not previously been subjected to theoretical modeling. One of such new directions in modern natural sciences and social development is presented in synergy. Synergetics is a direction and a general scientific program of interdisciplinary research that studies the process of selforganization and the formation of new orderly structures in open physical, biological, social, cognitive, informational, environmental and other systems. Synergetics gives a new image of the world. At the heart of the synergetic paradigm is a special relation to the problems of determinism and the emphasis on the processes occurring in the "exacerbation mode". Determinism captures the activity of being and states that any thing is the result of changing other things, they are rooted in them. The synergetic paradigm rests on a certain conceptual-categorical apparatus, an entropy-categorical apparatus: an entropy approach, chaos, bifurcation, dissipative system, disaster, self-motion, and others. No less important in synergy is the category of self-organization. Self-organization - an active process of formation, reproduction, preservation or improvement of the organization of a complex dynamic system, ensuring its normal existence and functioning as a holistic entity The urgency of researching the processes of self-organization is explained primarily by the need to solve the problem of creating on completely new principles of cybernetic systems capable of performing functions that have traditionally been considered the exclusive prerogative of the human brain. The synergistic experimental paradigm involves a rethinking of the phenomenon of fluctuations (from lat fluctuation - fluctuations) - (mathematics) fluctuations or some kind of periodic change, a random deviation from the mean value physics) accidental deviation of the value of the physical quantity from the average in a certain area of space or at a certain point in time; (finance) exchange rate fluctuations; (medicine) a symptom of the presence of fluid in the closed cavity of the body, which is available palpation. The more complex the system, the more there are various types of fluctuations that can threaten its stability. The system passing through the stability threshold falls into the critical state of the bifurcation (the branch point). It is at such a point that the system becomes unstable in relation to fluctuations and can move to a new sphere of stability, that is, to the formation of a new state. Thus, synergy with its interdisciplinary arsenal of methods can become an adequate tool for analyzing the complex dynamic processes occurring in nature and in modern society.

Key words: synergetics, entropy, bifurcation, chaos, dissipation, fluctuation, self-organization, nonlinearity, and others.

\section{Синергетично-рефлективна модель управління як сдиного соціального організму}

\author{
П.І. Берко, М.М. Дзера
}

Львівський національний університет ветеринарної медицини та біотехнологій імені С.3. Гжиџького, м. Львів, Украӥна 
Нині як ніколи радикально здійснюється сама система наукового пізнання, розмиваються чіткі межі між практичною та пізнавальною діяльністю. У системі наукового знання мають місце інтенсивні процеси диференціації та інтеграції знання, розвиваються комплексні дослідження, нові способи та методи пізнання, методологічні установки, зя́вляються нові елементи картини світу, викреслюються раніш невідомі, більш складні типи об'єктів пізнання, щу характеризуються історизмом, універсальністю, складністю організації, які раніше не піддавалися теоретичному моделюванню. Один з таких нових напрямків у сучасному природознавстві і суспільному розвитку представлено у синергетиці. Синергетика (від грецьк. sупегqеіа, який діє обопільно, узгоджено) - напрям $i$ загальнонаукова програма міжсисииплінарних досліджень, котрі вивчають процес самоорганізаиї та становлення нових упорядкованих структур у відкритих фізичних, біологічних, соціальних, когнітивних, інформачійних, екологічних та інших системах. Синергетика дає новий образ світу. В основі синергетичної парадигми лежить особливе відношення до проблем детермінізму і акиентування на процеси, шуо протікають у режимі “загострення”. Детермінізм фіксує активність буття та стверджує, щзо будь-яка річ є результатом зміни інших речей, в них закорінена. Синергетична парадигма опирається на певний понятійно-категоріальний апарат, ентропійно-категоріальний апарат: ентропігійний підхід, хаос, біфуркація, дисипативна система, катастрофа, саморух та ін. Не мени важливе місие в синергетиці займає категорія самоорганізаиї. Самоорганізація - активний процес формування, відтворення, збереження або удосконалення організацї складної динамічної системи, щзо забезпечує ї̈ нормальне існування і функціонування як иілісного утворення. Актуальність досліджень процесів самоорганізації пояснюється насамперед необхідністю вирішення проблеми створення на абсолютно нових принципах кібернетичних систем, здатних виконувати функиї, щзо традиційно вважалися винятковою прерогативою мозку людини. Синергетична дослідна парадигма включає в себе переусвідомлення феномену флуктуацї (від лат. fluсtиатіоп - коливання) (математика) коливання чи якась періодична зміна, випадкове відхилення від середнього значення величини; (фізика) випадкове відхилення значення фізичної величини від середнього в певній ділянці простору чи в певний момент часу; (фінанси) коливання обмінного курсу; (медицина) симптом наявності рідини в замкненій порожнині тіла, щзо доступна пальпації. Чим складніша система, тим більще існує різноманітних типів флуктуаціі, щзо можуть загрожувати ї̈ стабільності. Система переходячи через поріг стабільності потрапляє в критичний стан біфуркачії (точка розгалуження). Саме в такій точиі система стає нестабільною стосовно флуктуації і може перейти до нової сфери стабільності, тобто до формування нового стану. Отже, синергетика зі своїм міждисииплінарним арсеналом методів може стати адекватним інструментом для аналізу складних динамічних процесів, щчо відбуваються у природі і сучасному суспільстві.

Ключові слова: синергетика, ентропія, біфуркаџія, хаос, дисипація, флуктуація, самоорганізаџія, нелінійність та ін.

У сучасному світі поступово, але невблаганно зростає роль науки. На основі наукового знання раціоналізуються всі форми суспільного розвитку. Наука стала безпосередньою виробничою силою суспільства. Стосовно до практики вона виконує програмуючу роль. Нові інформаційні технології та засоби обчислювальної техніки, досягнення генної інженерії та біотехнологій обіцяють докорінним чином змінити матеріальну цивілізацію, переміну стилю нашого життя. Під впливом такого розвитку наукового мислення значно зростає роль особистості, роль людського фактору у всіх формах діяльності.

Разом з тим радикально змінюється й власне сама система наукового пізнання. Розмивається чітка межа між практикою та пізнавальною діяльністю. У системі наукового знання мають місце інтенсивні процеси диференціації та інтеграції знання, розвиваються комплексні дослідження, нові способи та методи пізнання, методологічні установки, з'являються невідомі елементи картини світу, викреслюються раніше невідомі, більш складні типи об'єктів пізнання, що характеризуються історизмом, універсальністю, складністю організації, які раніше не піддавалися теоретичному моделюванню. Один 3 таких нових напрямків у сучасному природознавстві і сучасному розвитку представлено у синергетиці. Синергетика (від грецьк. synerqeia, який діє обопільно, узгоджено) напрям і загальнонаукова програма міждисциплінарних досліджень, котрі вивчають процес самоорганізації та становлення нових упорядкованих структур у відкритих фізичних, біологічних, соціальних, когнітивних, інформаційних, екологічних та інших системах. Синергетика заснована на ідеях системності або цілісності світу і наукового знання про нього, спільності закономірностей розвитку об'єктів усіх рівнів матеріальної і духовної організації, нелінійності (тобто багатоваріантності і незворотності), глибинним взає- мозв'язком хаосу і порядку (випадковості і необхідності). Синергетика дає новий образ світу.

Термін “синергетика" наприкінці 1960-х років ввів Г. Хакен (ФРН). Для становлення синергетики важливе значення мали експериментальні результати, отримані Б. Білосовим і А. Жаботинським. Вони дослідили, що при взаємодії кількох речовин існує певне співвідношення їхніх концентрацій, навколо якого кінетика реакції стає циклічною: концентрація одного 3 реагентів то збільшується, то зменшується. За наявності барвника коливання візуалізується: червоний, синій, червоний, синій...При цьому можна спостерігати регулярну структуру спіралей чи циліндрів. Опираючись на них, бельгійська школа 3 I. Пригожиним побудувала першу нелінійну модель синергетики хімічних процесів, що грунтувалися на ідеях нерівномірної термодинаміки.

В основі синергетичної парадигми лежить особливе ставлення до проблеми детермінізму і акцентування уваги на процесах, що протікають у режимі “з загострення”. Детермінізм (від лат. - визначаю, обмежую) - теорія відносин опосередкування, завдяки яким продукуються речі та явища, визначається їхня природа і способи існування. Детермінізм відповідає на питання, чому виникає річ, чим вона породжена, чим визначається іiі існування і чому вона змінюється і зникає, у що перетворюється. Детермінізм фіксує активність буття та стверджує, що будь-яка річ $є$ результатом зміни інших речей і них закорінена. Синергетика у даному випадку констатує себе як концепція нерівномірної динаміки або теорії самоорганізації нелінійних динамічних процесів, задає нову матрицю бачення об'єкта як складного цілого.

Синергетична парадигма опирається на певний понятійно-категоріальний апарат. Наприклад, на загальнонаукове поняття як ентропійний підхід (від грецьк. - поворот. Зміна, перетворення) - частина 
внутрішньої замкнутої системи або енергетична сукупність Всесвіту, яка може перейти або бути перетворена в механічну роботу, тобто уникає жорсткої детермінації Всесвіту.

В інтерпретації хаосу (від грецьк. - безпорядок) синергетична парадигма робить акцент на те, що хаос $\epsilon$ складною і непередбачуваною формою порядку (а ніяк не антитезою порядку). Відтак поняття хаосу можна проілюструвати трьома моделями. У першій 3 них хаос виступає як турбулентність, тобто сукупність різноманітних турбулентних рухів, що попри це зберігає когерентність (від лат. - бути взаємозв'язаним). Друга модель подає хаос як деструктивну гілку еволюції. Хаос - “деструктор” породжує альтернативний шлях еволюції, що змінює напрямок самоорганізації у коливальному, циклічному чи динамічному режимах. Стосовно третьої моделі, то в ній хаос існує як сукупність можливостей різних шляхів еволюції, що не зводяться до траєкторії ані до комплексу траєкторій (Cikin, 2003).

У цілому синергетична модель виглядає так: повний хаос (немає організації), поява неживої матерії, поява живої організованої матерії, поява людського інтелекту. І це все внаслідок хаотичних рухів! Найбільше, що може виникнути у системі елементів, які рухаються хаотично - це узгодження їхнього руху, тобто організація примітивного рангу. 3 хаотичного руху не народжується нічого, окрім руху, навіть, якщо цей рух взаємоузгоджений і навіть, якщо у рухливих частинах закладена енергія.

У трактування біфуркації (від лат. - роздвоєння) синергетика виходить 3 того, що можна йти одним шляхом, а можна йти і по-іншому. Біфуркація - це одномоментний стан, коли система втратила стійкість i iï подальша еволюція виявляється принципово непередбачуваною, оскільки визначається тільки тими випадковими факторами, які в момент біфуркації діють на систему. Біфуркація має місце тоді, коли певні величини, що визначають основні властивості системи, досягають свого критичного значення, при якому кількісній еволюції системи відбуваються якісні зміни. Зміна означає розгалуження старої якості на кінцеву кількість нових якостей.

Низка біфуркацій може вивести систему 3 того стану, в якому вона перебувала, але може й повернути iii в цей же стан. Проте для кожної системи існує такий граничний стан, досягнувши якого система вже не може повернутися у вихідний стан. Такий стан називається атрактором - цільовий кінцевий стан системи. Атрактори можуть бути як правильними, що просто описуються структурами, так і хаотичними станами. У першому випадку атрактори характеризуються або одним кінцевим станом, або циклічно повторюваним процесом, що задається простою математичною формулою. У системах же детермінованого хаосу атрактори набувають більш складної структури і стають “дивними атракторами” (Haken, 1980).

Політичний тезаурус утворюється політичними біфуркаціями, в ролі яких виступають кризи, що періодично спостерігаються в кожному суспільстві. Кризи виступають як глобальні біфуркації, що назрівають зазвичай у кризових ситуаціях, що пов'язані з окре- мими особами. Кризовий стан суспільства передбачає виникнення певного набору нових можливих соціальних структур, реалізація кожної з яких може поновити втрачену рівновагу між глобальною структурою соціальної системи та ії̈ елементами.

Синергетика постала не на порожньому місці. Вона виникла на стику теоретичної фізики, механіки, кібернетики, озброївшись математичним апаратом та ін. Одним із ключових іï понять стало поняття дисипативної системи (дисипація - розповсюдження, “розпилення", речовини, енергії тощо). Своєрідність дисипативної системи полягає у тому, що сама можливість іiі існування перебуває в прямій залежності від можливості постійного обміну із середовищем речовиною, енергією чи інформацією. Наприклад, існування і розвиток системи "громадське суспільство" може відбутися постільки, поскільки система зможе обмінюватися інформацією (ідеями) із середовищем структурними елементами державного організму, адекватно відповідати на виклики 3зовні, пристосовуючись до навколишнього довкілля та змінюючи при цьому відповідним чином свої внутрішні параметри. У разі порушення такого обміну настає стагнація системи яка призводить до іiі зруйнування. Аналіз стану громадського суспільства, наприклад у державах 3 тоталітарними режимами (окремі періоди в історії Німеччини, Гвінеї чи СРСР) чи абсолютистських дає багатий матеріал на користь даного твердження.

Громадське суспільство, яке, за Джоном Кіном, $\epsilon$ складним і рухливим комплексом захищених законом недержавних інституцій, здебільшого ненасильницьких, самоорганізованих, саморегульованих, які до того ж перебувають у постійному зв'язку один з одними та 3 державними інституціями, звужуючи та водночас уможливлюючи діяльність останніх, перебувало вкрай в аморфному стані в одних випадках та майже повністю завмирало в інших.

Дисипативні системи характеризуються відкритістю, нерівноважністю, нелінійністю. Відкритість системи означає наявність у ній джерел і стоків обміну речовиною, інформацією чи енергією 3 зовнішнім середовищем. При цьому система, здатна до самоорганізації, має безліч точок-джерел і точок-стоків. Відтак обмін із середовищем відбувається не лише в певному місці системи, а й у кожній iї точці. Наприклад, якщо система “політична думка" $є$ певною системою ідей, то обмін із середовищем політикумом відбувається через кожного суб'єкта-носія ідеї чи ідей, інтелектуальна діяльність якого уможливлює саме існування політичної думки (Knjazeva \& Kurdjumov, 2010).

Стосовно такої основоположної характеристики дисипативної системи, як нерівноважність зауважимо таке. Нерівноважність є свідченням наявності внутрішньосистемного макроскопічного обміну речовиною, енергією, інформацією. Такий обмін $є$ у відкритій системі будь-якого походження - біологічного, політичного, соціального тощо.

Нелінійність дисипативної системи виражається у здатності останньої до самодії. Якщо лінійні системи (у яких відсутня здатність до самодії) реагують на зовнішній вплив прямо пропорційно, якщо зовнішній 
вплив незначний, то й зміни у системі будуть відповідно незначними, і навпаки - значний вплив обумовлює значні зміни. У нелінійних системах все зовсім інакше. Самодія може обумовити той факт, що дуже обмежений, ледь помітний вплив спричинить великі зміни, а значний вплив обумовить майже непомітні, невідчутні зміни. Тобто віддача не завжди залежить від кількості докладених зусиль, від вкладеної енергії.

У світоглядному аспекті ідея нелінійності може бути представлена у вигляді ідеї багатоваріантності чи альтернативності шляхів розвитку, ідеї незворотності. Наприклад, варіантами нелінійного розвитку $є$ розвиток у вигляді спіралі, зигзага, маятникової пульсації, петлі, накладених хвиль чи взаємовкладених спіралей.

Категорія складності в синергетиці означає не тільки нелінійність, а й наявність в системі чималої кількості елементів з великим ступенем свободи. Наприклад, у нинішньому українському політикумі вкрай сегментованому організмі як у складній системі присутні елементи (суб'єкти політики чи політичні актори), поведінка яких не може бути прогнозованою. Інший приклад: ретроспективний погляд на українську історію i, зокрема, на розвиток української нації на іншому віковому порубіжжжі - у кінці XIX - на початку XX ст. розвиток української еліти свідчить, що і в той момент українські історії, як і будь-який інший, завжди були в наявності ті, приміром, особистості, хід розвитку політичного думання яких, політична поведінка випадали, так би мовити, із загального русла, заданого російською чи радянською імперською потугою. Наслідком було постання в одному випадку українського соціалізму драгоманівського типу, в іншому - українського націоналізму i, зрештою, у кінці десятих років XX ст. українського націоналкомунізму тощо.

Вважаємо необхідним розкрити суть націоналізму, українського націоналізму, українського соціалізму драгоманівського типу i українського націоналкомунізму, що краще пізнати специфіку нелінійності. Націоналізм - спрямування політичної думки, політична ідеологія та політична практика, в центрі уваги яких перебуває нація як ідея (або поняття) та як цінність. Український націоналізм - деяка сукупність ідей та уявлень, в яких наголошується на цінності нації. Так, ідеологія націонал-демократизму (з к. 80-х та в 90-ті рр. XX ст.) зберігає наголос на цінності нації як носія культурної ідентичності та державної незалежності, з одного боку, та гаранта прав людини, з іншого. У системі цінностей беззастережний пріоритет у творчості М. Драгоманова віддано людині, іï свободі й гідності, а його соціалістичні ідеї мають етичне забарвлення (“етичний соціалізм”), у світлі якого піддано критиці як російське народництво 3 його націленості на бунт, так і марксизм з його революціонаризмом. Вчений поверхнево трактує поняття “націоналізм”, надає пріоритету поняттю “національність”. Націонал-комунізм - ідейно-політична течії в національно-визвольному русі, які боротьбу за соціалізм ставлять у залежність від розв'язання завдань цього руху (носіями націонал-комунізму були М. Хвильовий, М. Волобуєв та ін.). Появу цих фено- менів, їх розвиток можна зрозуміти, ставши на позиції синергетики та сприйнявши ідею нелінійності, складності.

Синергетика по-новому трактує значення випадковості. Випадковість не $є$ побічною другорядною особливістю перетіканні процесів. Вона цілком стала, характерна риса, умова існування та розвитку об'єктивного світу. випадок, як свідчить світовий політичний процес, досить часто призводить до величезних потрясінь (пригадаймо хоча б подію, що була приводом до Другої світової війни), зумовлює разючі зміни як в політичному житті окремого народу чи держави, так і в напрямку розвитку цілих регіонів цивілізацій.

Синергетика послуговується категорією “катастрофа". Слово “катастрофа" тут використовується не тільки в його традиційному змісті (тобто як символ руйнування, загибелі, знищення), а й як загальнонауковий термін, що означає будь-яку стрибкоподібну зміну, котра виникає у поведінці природних, соціальних, технічних систем у вигляді раптових відповідей цих систем на повільну зміну зовнішніх умов. Термін “катастрофа" (у цьому сенсі) може слугувати виразом творчих, креативних, конструктивних процесів (таких, напр., як спонтанне виникнення фізикокосмічних реалій, які раніше не існували, зародження біологічних видів, спонтанна поява якісно нових режимів тощо).

Синергетика торкається не лише практичних проявів катастроф, вона акцентує нашу увагу і на теорію катастроф, теорію у галузі біологічних наук, сформульовану 1812 р. Ж. Кювє (1768-1769 рр.), згідно 3 якою в історії Землі періодично траплялися катастрофи, що змінювали будову Землі та знищували органічний світ, котрий згодом створювався заново у кращій формі. Крім того, ця теорія $є$ ефективним знаряддям моделювання еволюції складних динамічних систем, які використовуються в усіх галузях життєдіяльності сучасної техногенної цивілізацій. Сфера застосувань концепції катастрофізму неозора.

Не менш важливим для синергетики є саморух внутрішня необхідність спонтанних змін системи, яка визначає іiі протиріччя. Висунута синергетична концепція самоорганізації служить природно-науковим уточненням принципу саморуху і розвитком матерії. На противагу класичній механіці, що розглядає матерію як закостенілу масу (що приводиться в рух зовнішньою силою), у синергетиці виявляється, що в певних умовах системи неорганічної природи здатні до самоорганізації. Самоорганізація - активний процес формування, відтворення, збереження або удосконалення організації складної динамічної системи, що забезпечує іiі нормальне існування і функціонування як цілісного утворення. Самоорганізація - це іманентна здатність динамічної системи самостійно підтримувати, відтворювати чи удосконалювати рівень своєї організації при зміні зовнішніх чи внутрішніх умов іiі існування і функціонування, спрямована на підвищення іï стійкості, збереження цілісності, забезпечення ефективних дій чи розвитку. Спеціальні дослідження проблем синергетики вперше було почато в кібернетиці, термін “самоорганізуюча система" за- 
пропонував англійський вчений У.Р. Ешбі (1947). Актуальність досліджень процесів самоорганізації пояснюється насамперед необхідністю вирішення проблеми створення на абсолютно нових принципах кібернетичних систем, здатних виконувати функції, що традиційно вважалися винятково прерогативними мозку людини. Перші дослідження феномена самоорганізації з метою побудови теорії самоорганізуючих систем як основи моделювання складних процесів (інтелектуальних, біологічних соціальних) засвідчили, що перед науковим пізнанням постав принципово новий клас проблем, вирішення яких вимагає розробки нетрадиційних, оригінальних засобів дослідження. Проблема передовсім полягала в необхідності визначення й окреслення класу систем (реальних і принципово можливих), які б адекватно характеризувалися поняттям самоорганізація. Клас самоорганізуючих систем, окреслений рамками кібернетичного трактування самоорганізації, досить широкий. Вони можуть бути різними за своєю природою, рівнем складності, організації, стійкості, цілеспрямованості, автономності та ін. (жива клітина, організм, популяція, людський колектив, комп'ютер тощо). Процеси самоорганізації тісно пов'язані з низкою інших процесів - адаптації, самонастрою, самокерування, самовідтворення, саморозвитку, самонавчання та ін.

В основі будь-якої самоорганізуючої системи лежить самоорганізація, котра $є$ феноменом, який властивий виключно людському співтовариству. 3 хаосу як енергійного і безладного саморуху елементів при вмілому і ефективному управлінні виникає самоорганізація, яка сприяє стабілізації і зміцненню суспільства і переростає в регулювання як соціальний організм, в якому кореляційні зв'язки між елементами системи працюють чітко, узгоджено, визначено. Концепції самоорганізації набули розвитку в 50-60 pp. ХХ ст. на основі статичної фізики (І. Пригожин, Г.Хакен), загальної теорії систем і кібернетики (Г. Ферстер, Х. Матурана), які вивчали закономірності виникнення структури в нерівноважених системах, що складалися 3 неупорядкованих елементів.

Синергетична дослідна парадигма включає в себе переусвідомлення феномену флуктуація (від лат. коливання) - (математика) коливання чи якась періодична зміна, випадкове відхилення від середнього значення величини; (фізика) випадкове відхилення значення фізичної величини від середнього в певній ділянці простору чи в певний момент часу; (фінанси) коливання обміну курсу; (медицина) симптом наявності рідини в замкненій порожнині тіла, що доступна пальпації. Чим складніша система, тим більше існує різноманітних типів флуктуації, що можуть загрожувати іiї стабільності. Але в складних системах існують багатоманітні типи зв'язків між різними частинами систем. Від наслідків конкуренції між стабільністю, що забезпечується зв'язком, та нестабільністю через флуктації залежить поріг стабільності системи. Система, переходячи через поріг стабільності, потрапляє в критичний стан біфуркації (точку розгалуження). Саме в такій точці система стає нестабільною стосовно флуктуації і може перейти до нової сфери стабільності, тобто до формування нового стану. Система нібито коливається перед вибором одного 3 кількох шляхів розвитку. У відкритих нелінійних середовищах (а саме такі системи є найбільш типовими в світі, в якому ми живемо) мале діяння, флуктуація, випадковість можуть призводити до значних наслідків. Малі флуктації, замість того, щоб затухали можуть підсилюватись, і система еволюціонуватиме в напрямку “спонтанної організації”, тобто невелика флуктуація може служити початком еволюції в принципово новому напрямку, що різко змінює всю поведінку макроскопічної системи. Так, стосовно таких станів можливо робити деякі передбачення, тому що незважаючи на непередбачуваність флуктуації (випадкових змін початкових умов), набір можливих транс-теорій - шляхів еволюції системи - обмежений (наприклад, погодні умови, що можна спостерігати в певному сезоні, в певному регіоні). Випадкові флуктуації непередбаченим чином змінюють траєкторію систем, хоча самі траєкторії мають тяжіння до певних типів а тракторів (новий етап розвитку) - внаслідок чого переводять систему, нестабільну стосовно початкових умов, в новий стабільний стан. Ілля Пригожин виражає це словами - із флуктуацій шумів народжується новий порядок. У нерівноважених системах може відбуватися перехід від безладдя до впорядкованості

Таким чином, синергетика є новим мисленням посткласичної науки, це синтез ймовірності картини світу, системних досліджень, що дозволяють розкрити принципи еволюції складних систем, розкрити причини хаосу, криз, опанувати методами нелінійного керування складними системами. Ця галузь знань вирішує проблему того, як керувати, як за допомогою малого резонансного впливу підштовхнути систему на один з їі власних і сприятливих для суб'єкта шляхів розвитку, як переборювати хаос, роблячи його творчим, перетворюючи в поле для народження нового. Це шлях творення, можливість нового діалогу людини з природою. Здійснюючи вибір шляху через нелінійну ситуацію, біфуркацію, суб'єкт одночасно вибирає об'єктивно властивий самій природі шлях еволюції. Синергетика і виникла як відповідь науки на виклик дійсності на шляху прямування природним шляхом розвитку речей.

\section{References}

Cikin, V.A. (2003). Teorija samoorganizacii sovremennaja paradigma obrazovanija i formirovanie modeli uchitelja. Prakt. Filosofija, 1, 174-172 (in Russian).

Haken, G. (1980). Sinergetika. Moskva, Mir (in Russian). Knjazeva, E.N., \& Kurdjumov, S.P. (2010). Osnovanija sinergetiki. Sinergeticheskoe mirovidenie. M.: KomKniga, Izd.3, dop. M.: URSS (in Russian). 